\title{
UMOWA O UDOSTĘPNIENIE SKRYTKI BANKOWEJ W PRAWIE FRANCUSKIM
}

\section{UWAGI WSTĘPNE}

Umowa o udostępnienie skrytki bankowej, zwana także „umową najmu skrytki”, „umowa sejfu bankowego" czy „umową sejfowa” ${ }^{1}$ nie jest uregulowana w prawie polskim. Jedynie art. 5 ust. 2 pkt 6 Prawa bankowego ${ }^{2}$ wymienia, obok przechowywania przedmiotów i papierów wartościowych, udostępnianie skrytek sejfowych jako jedną z czynności bankowych. Przepis ten nie przesadza jednak ani o treści, ani o kwalifikacji prawnej tej umowy³. Szczegółowe postanowienia dotyczące m.in. jej zawarcia, przedmiotu i treści zamieszczone są w regulaminach bankowych.

Taki stan regulacji umowy o udostępnienie skrytki bankowej rodzi wiele wątpliwości, zwłaszcza co do praw i obowiązków stron, zakresu odpowiedzialności banku oraz charakteru prawnego umowy. Wymienione zagadnienia maja ogromną doniosłość praktyczną, gdyż znaczenie umowy sejfowej niewątpliwie wzrosło ze względu na oczywistą tendencję do przechowywania szczególnie cennych przedmiotów poza domem. Prace nad projektem nowego kodeksu cywilnego stwarzają doskonała okazję do rozważań na temat normatywnego kształtu tej umowy i ewentualnego uregulowania jej w tym akcie prawnym. Pomocne $\mathrm{w}$ prowadzeniu prac legislacyjnych będzie sięgnięcie do dorobku

${ }^{1}$ Jest to wyliczenie przykładowe. Zob. np. M. Kasprzak, Umowa sejfowa, „Glosa” 1996, nr 1, s. 2; M. Bączyk, Umowa sejfu bankowego, w: System prawa prywatnego, t. 9: Prawo zobowiazań umowy nienazwane, red. W. Katner, Warszawa 2010, s. 662-665.

${ }^{2}$ Dz. U. 1997, Nr 140, poz. 939 ze zm.

${ }^{3}$ Według niektórych badaczy umowę tę należy zakwalifikować jako umowę nienazwaną z elementami umowy przechowania. Zob. np. J. Napierała, Przechowanie, w: System prawa prywatnego, t. 7: Prawo zobowiqzań - część szczegółowa, red. J. Rajski, Warszawa 2011, s. 773. Sa też głosy, według których umowa ta jest oryginalnym typem nienazwanej umowy bankowej albo umowa przechowania w znaczeniu szerokim. Tak. np. M. Kasprzak, Umowa sejfowa, „Glosa” 1996, nr 1, s. 2; M. Bączyk, Umowa sejfu bankowego, w: System..., t. 9, s. 662. Sąd Najwyższy natomiast w wyroku z 26 lipca 2001 r., II CKN 1269/00, wyraził pogląd, że umowa sejfowa ma mieszany charakter i zawiera elementy zarówno najmu, jak i przechowania - OSP 2002, nr 9, poz. 121. Takie stanowisko prezentuje także A. Szpunar, Umowa o udostepnienie skrytki bankowej, „Przegląd Sądowy" 2003, nr 2, s. 3. 
naukowego tych państw, w których umowa sejfowa - podobnie jak w prawie polskim - nie jest uregulowana w ustawie, lecz w regulaminach bankowych. Należy do nich prawo francuskie, będące przedmiotem niniejszego artykułu.

Judykatura i doktryna francuska już dawno zauważyły problemy łączące się z umową sejfową (fr. contrat de location de coffre-fort), o czym świadcza liczne orzeczenia sądowe oraz bogate piśmiennictwo. Poruszają one zwłaszcza problematykę charakteru prawnego tej umowy, odpowiedzialności banku za niewykonanie lub nienależyte wykonanie obowiązku pieczy nad skrytka, wysokości odszkodowania, czy dopuszczalności umieszczenia w umowie klauzul ograniczających odpowiedzialność banku. W dalszych rozważaniach uwaga zostanie zwrócona tylko na wybrane elementy umowy sejfowej w prawie francuskim, to jest na zawarcie i strony umowy, ich prawa i obowiązki, charakter prawny oraz odpowiedzialność banku za niewykonanie lub nienależyte wykonanie obowiązu pieczy nad skrytka, a także na pełnomocnictwo do korzystania ze skrytki.

\section{ZAWARCIE I STRONY UMOWY}

Samo zawarcie umowy nie wywołuje problemów w praktyce. Powszechnie uznaje się, że jest to kontrakt adhezyjny (contrat d'adhésion), do którego zawarcia wystarcza zwykła forma pisemna. Warunki umowy określone sa najczęściej w regulaminie banku albo w osobnym dokumencie przekazywanym klientowi przy zawarciu umowy. Może on zatem, jeśli je akceptuje, zawrzeć umowę z bankiem, albo jeśli uważa, że postanowienia te sa dla niego niekorzystne, odmówić jej podpisania. W razie waţpliwości, czy umowa jest ważna, stosuje się ogólne zasady prawa cywilnego dotyczące zawierania kontraktów ${ }^{4}$. Umowę o udostępnienie skrytki bankowej strony mogą zawrzeć na czas określony albo nieokreślony. Domniemywa się milczące przedłużenie stosunku obligacyjnego, jeśli klient po upływie określonego w umowie czasu nie odda bankowi klucza do skrytki. Każda ze stron ma też kompetencję do jednostronnego wypowiedzenia umowy w dowolnym czasie.

Bank wydaje klientowi klucz, którego nie wolno duplikować ani udostępniać nieupoważnionym osobom trzecim. Drugi klucz znajduje się w posiadaniu banku. Otwarcie skrytki możliwe jest wyłącznie przy pomocy pracownika banku (przeważnie dozorcy) i jej posiadacza, ale tylko ten ostatni zna szyfr pozwalajaccy na jej otwarcie.

Umowa sejfowa należy do umów zawieranych intuitu personae. Oznacza to, że bank może odmówić podpisania umowy z określonym „podejrzanym” klientem, a temu ostatniemu nie przysługuje prawo do korzystania ze skrytki

${ }^{4}$ Tak P. Bertran de Balanda, La convention de coffre-fort. Formation et preuve du contrat, „Petites affiches” 1977, nr 31, s. 16-17. 


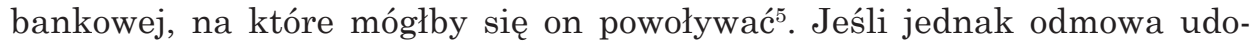
stępnienia skrytki ma charakter abuzywny, klient może wystapić do sądu $\mathrm{z}$ roszczeniem o zawarcie umowy.

Przed podpisaniem umowy bank sprawdza tożsamość klienta, miejsce zamieszkania, a także często pobiera próbki pisma. Leży to zarówno $\mathrm{w}$ interesie banku, jak i jego klientów będących już posiadaczami skrytek ${ }^{6}$. Te wstępne czynności umożliwiają bankowi dokonanie pewnej selekcji klientów, a tym samym pozwalają na zwiększenie bezpieczeństwa przedmiotów znajdujących się w skrytce. Po zawarciu umowy nie jest on już najczęściej w stanie sprawdzić, czy klient nie umieszcza w skrytce przedmiotów, których złożenie do skrytki jest wyłączone. Tym samym takie środki ostrożności moga uchronić bank przed późniejszą odpowiedzialnością wobec pozostałych klientów (np. klient umieszcza w skrytce bombę, której wybuch niszczy inne skrytki i ich zawartość). Gdy strona umowy sejfowej jest osoba prawna, bank sprawdza, kto jest uprawniony do otwarcia skrytki, żądając przy zawarciu umowy wyciagu z rejestru, ewentualnie, jeśli podmiot w nim nie figuruje, dostarczenia wyciagu ze statutu?

Przedmiotem zainteresowania doktryny jest także kwestia zawarcia umowy sejfowej przez małoletniego (mineur) i osobę będaca pod kuratela (majeur en curatelle). W pierwszej sytuacji oczywiste jest, że w imieniu małoletniego występuje jego opiekun prawny i tylko on może umieszczać przedmioty w skrytce, do czego nie potrzebuje zgody sądu. Inna sytuacja występuje w przypadku konta bankowego, z którego może korzystać swobodnie sam małoletni, pod warunkiem że posiada zgodę swojego przedstawiciela ustawowego. Z kolei osoba będąca pod kuratelą może samodzielnie korzystać ze skrytki. Gdyby jednak jej stan zdrowia stał temu na przeszkodzie, sąd ustanowi dla niej kuratora do pomocy przy tej czynności ${ }^{8}$.

Po stronie klienta może występować więcej niż jedna osoba. Należy podkreślić, że dostęp do skrytki dla większej liczby osób musi wynikać jednoznacznie z umowy. Jak zaznacza M. Cabrillac, ze skrytki bankowej nie może korzystać osoba, co do której takie prawo się jedynie domniemywa ${ }^{9}$. W praktyce bardzo często umowę sejfową zawierają małżonkowie. Mogą oni wówczas korzystać ze skrytki wyłącznie razem, jednocześnie obecni albo też osobno, w zależności od przyjętego w umowie reżimu. W pierwszej sytuacji, jeśli jeden z nich umiera, to dostęp do skrytki zostaje zablokowany aż do momentu uregulowania spraw spadkowych. W drugim przypadku każdy z małżonków może działać samodzielnie (tzw. location jointe), a śmierć jednego $\mathrm{z}$ nich nie powoduje utraty możliwości korzystania ze skrytki ${ }^{10}$.

${ }^{5}$ Odwrotnie natomiast dzieje się w przypadku konta bankowego - uznaje się bowiem powszechnie, że prawo do jego posiadania przysługuje każdemu. Zob. S. Piedelièvre, E. Putman, Droit bancaire, Paris 2011, s. 746.

${ }^{6}$ J. P. Deschanel, Le contrat de coffre-fort, „Le droit et la banque” 1973, nr 317, s. 348.

7 Tak S. Piedelièvre, Coffre-fort, „Répertoire de droit commercial” 2006, nr 5, s. 2.

${ }^{8}$ Zob. szerzej, P. Bertran de Balanda, op. cit., s. 16-17.

${ }^{9}$ Zob. M. Cabrillac, B. Teyssié, Crédit et titres de credit, „Revue trimestrielle de droit commercial et de droit économique" 1986, nr 2, s. 279-280.

${ }^{10}$ Ch. Gavalda, J. Stoufflet, Droit bancaire, Paris 2008, s. 587. 


\section{PRAWA I OBOWIĄZKI STRON}

Bank udostępnia klientowi skrytkę, a ten może, ale nie musi, umieszczać w niej różne przedmioty. Najczęściej są to papiery wartościowe, akty własności, obrazy oraz listy. Klient zobowiązuje się nie umieszczać w skrytce przedmiotów niebezpiecznych lub łatwo psujących się, wyłączonych w umowie, takich jak materiały łatwopalne, broń, narkotyki. Skrytki znajdują się przeważnie w podziemiach banku, w specjalnie przygotowanym do tego pomieszczeniu, które zapewnia klientowi banku możliwość swobodnego dostępu do skrytki i przeglądania jej zawartości. W tym ostatnim celu bank udostępnia klientowi zazwyczaj osobną salę, przylegającą do pomieszczenia ze skrytkami.

Do obowiązków banku należy zapewnienie klientowi dostępu do skrytki. Co zrozumiałe, nie jest on, ze względu na bezpieczeństwo skrytek, nieograniczony. Klient może z nich korzystać wyłącznie w dniach i godzinach pracy banku, przy współdziałaniu upoważnionego pracownika, który dysponuje drugim kluczem. Do zadań tego ostatniego należy również sprawdzanie tożsamości i umocowania osoby chcacej skorzystać ze skrytki.

Ponadto do obowiązków banku należy ścisła ochrona skrytki, a co za tym idzie - także przedmiotów w niej złożonych. Ze względu na naturę umowy sejfowej obowiązki te mają znaczenie fundamentalne ${ }^{11}$. Powodem bowiem, dla którego klient banku decyduje się na złożenie wartościowych przedmiotów do skrytki bankowej, jest chęć zapewnienia im maksimum bezpieczeństwa, przy braku wiedzy banku na temat tego, co, jeśli w ogóle, się w niej rzeczywiście znajduje. Innymi słowy, klient za przeważnie niską opłata uzyskuje bezpieczeństwo złożonych w skrytce przedmiotów oraz pełną dyskrecję banku, gdyż ten związany sekretem bankowym nie ma nawet prawa ujawniać osobom trzecim, czy dana osoba jest posiadaczem skrytki.

Zapewnienie bezpieczeństwa skrytki przejawia się w dwóch aspektach. Po pierwsze, wyraża się ono w kontroli osób, które chcą uzyskać do niej dostęp. Powszechnie w doktrynie uznaje się, że działania banku w tym zakresie sa zobowiązaniami starannego działania. Oznacza to, że bank ponosi odpowiedzialność za niedochowanie należytej staranności i może uwolnić się od odpowiedzialności, jeśli wykaże, że tej należytej staranności dochował. Z tego względu pracownicy banku powinni bardzo starannie sprawdzać tożsamość klienta oraz ważność ewentualnych pełnomocnictw. Co ciekawe, sąd zwolnił jednak bank od odpowiedzialności za niezachowanie należytej staranności w sytuacji, gdy ten pozwolił na korzystanie ze skrytki klientowi w trakcie rozwodu, legitymującemu się pełnomocnictwem oraz jednocześnie podrobionym zaświadczeniem o zgubieniu klucza do skrytki ${ }^{12}$.

Po drugie, zagwarantowanie bezpieczeństwa skrytki przejawia się w pieczy nad samymi skrytkami i przedmiotami w nich złożonymi. Chodzi tu przede wszystkim o umieszczenie skrytek w pomieszczeniu nienarażonym na powódź, z odpowiednimi zabezpieczeniami przeciwpożarowymi oraz systemem

${ }^{11}$ M. Cabrillac, B. Teyssié, op. cit., s. 285.

${ }^{12}$ Zob. szerzej, T. Bonneau, Droit bancaire, Paris 2007, s. 598. 
antywłamaniowym. Ważna jest również sama ich konstrukcja. To właśnie ona, a nie osoba bankiera, ma najczęściej decydujący wpływ na decyzję klienta co do zawarcia umowy sejfowej z danym bankiem ${ }^{13}$.

Kwalifikacja zobowiązania banku do ochrony samej skrytki i jej zawartości wzbudzała w doktrynie wątpliwości. Nie było bowiem zgodności poglądów co do tego, czy jest to zobowiązanie starannego działania, czy zobowiązanie rezultatu. W tym pierwszym przypadku łatwiej byłoby bankowi uwolnić się od odpowiedzialności, gdyż wystarczyłoby, że wykaże on, iż dochował należytej staranności. Natomiast jeśliby przyjąć, że zobowiązanie banku do ochrony skrytki jest zobowiąaniem rezultatu, to wówczas bank nie ponosiłby odpowiedzialności, jeśli wykazałby, że to działanie siły wyższej uniemożliwiło mu osiagnięcie ustalonego w umowie rezultatu, czyli nienaruszalności skrytki. Przyjęcie takiej kwalifikacji byłoby korzystne dla klienta, ponieważ zakłada ona domniemanie winy banku w sytuacji nieosiagnięcia ustalonego w umowie rezultatu. Watpliwości te zostały jednak jednoznacznie rozstrzygnięte przez Cour de cassation, który orzekł, że „na banku ciąży zobowiązanie rezultatu względem najemcy skrytki i jest on odpowiedzialny za kradzież złożonych w skrytce przedmiotów, nawet jeżeli należą one do osoby trzeciej"14.

Z kolei do obowiązków klienta należy korzystanie ze skrytki zgodnie z umową i regulaminem banku. Ma on zatem prawo dostępu do skrytki w godzinach i dniach pracy banku. Nie może umieszczać w niej przedmiotów niebezpiecznych, zakazanych przez prawo czy też łatwo psujących się. Jeśli wymagaja tego przepisy prawa, powinien on złożyć deklarację, jakie przedmioty składa do skrytki i czy, na przykład, podlegają one reglamentacji. Przyjmuje się, że skoro bank nie zna zawartości skrytki, nie można obciążać go odpowiedzialnością za sprzeczne z prawem działania klienta.

Obowiązkiem tego ostatniego jest również zapłata wynagrodzenia za korzystanie ze skrytki. Jego wysokość określa jednostronnie bank w umowie albo regulaminie i nie podlega ona negocjacji. Co do oceny działania banku w zakresie ustalania wynagrodzenia, sądy francuskie zastrzegały sobie prawo kontroli jego wysokości przez badanie dobrej wiary banku podczas zawierania umowy. Obecnie przyjmuje się, że banki mają swobodę w określaniu wysokości wynagrodzenia, jakie płaci klient za korzystanie ze skrytki, ale sąd może sprawdzić, czy takie postanowienia nie mają charakteru abuzywnego. Co ciekawe, Cour de cassation nie przyznał takiego charakteru klauzuli, na podstawie której bank podniósł czynsz o $150 \%{ }^{15}$.

Bardzo często bank zastrzega w umowie zapłatę wadium (dépôt de garantie). Ma ono na celu zabezpieczenie jego roszczeń w przypadku niewywiązywania się klienta z umowy. W szczególności chodzi tutaj o koszty otwarcia skrytki w sytuacji, gdy mimo wygaśnięcia kontraktu klient nie wyjmuje ze skrytki złożonych w niej przedmiotów albo nie oddaje klucza. Wówczas pra-

\footnotetext{
${ }_{13}$ Zob. szerzej M. Leven, Les cases de coffres-forts devant la loi..., s. 247.

${ }^{14}$ Zob. R. Routier, Obligations et responsabilités du banquier, Paris 2011, s. 467; Cour de cassation, Chambre civile $1^{\text {re }}, 29$ mars 1989, nr 87-17.262.

${ }^{15}$ F. Dekeuwer-Défossez, S. Moreil, Droit bancaire, Paris 2010, s. 186; Cour de cassation, Chambre civil $1^{\text {re }}$, 30 juin 2004, nr 00-00475.
} 
cownik banku w obecności komornika otwiera ją i składa do zapieczętowanej koperty znajdujące się w niej przedmioty. Zdarza się także, że jeśli klient zawiera umowę o prowadzenie rachunku bankowego, to pozostawia na nim sumę w wysokości wadium, a także zezwala bankowi na pobieranie z jego konta miesięcznego czynszu za korzystanie ze skrytki ${ }^{16}$.

\section{CHARAKTER PRAWNY UMOWY O UDOSTĘPNIENIE SKRYTKI BANKOWEJ}

Charakter prawny umowy o udostępnienie skrytki sejfowej wciąż wywołuje ogromne kontrowersje, o czym świadczą liczne orzeczenia sądów francuskich $^{17}$. Ustalenie tego charakteru, jak się uważa, jest bardzo istotne, ponieważ determinuje reżim odpowiedzialności odszkodowawczej. Nie jest to zatem wyłącznie kwestia teoretyczna, ale ma ona doniosłe znaczenie praktyczne ${ }^{18}$. Są jednak autorzy, którzy kwestionują doniosłość tego sporu.

W pierwszej kolejności rozważa się kwalifikację umowy sejfowej albo jako rodzaj umowy przechowania, albo umowy najmu. Zgodnie z art. 1917 i n. Code civil $^{19}$ umowa przechowania jest co do zasady umowa bezpłatna, a jej przedmiotem mogą być wyłacznie rzeczy ruchome. Zawarcie umowy może mieć obligatoryjny albo dobrowolny charakter i następuje przez przekazanie rzeczy na przechowanie. Do obowiązków przechowawcy należy zapewnienie nad tą rzeczy pieczy takiej, jakiej należałoby się spodziewać, gdyby przedmiot stanowił własność samego przechowawcy. Ponadto bez zgody oddajacego na przechowanie przechowawca nie może przedmiotu przechowania używać ani przenosić w inne miejsce. Code civil przewiduje także w kilku przypadkach surowsza odpowiedzialność przechowawcy (m.in. w sytuacji, kiedy przechowanie jest odpłatne).

Tak określone obowiązi przechowawcy pokrywaja się z obowiązkami banku w umowie sejfowej. Zwłaszcza charakterystyczny dla umowy sejfowej obowiązek pieczy jest tożsamy z takim obowiązkiem w umowie przechowania. Pojawia się zatem pytanie, czy wskazane powyżej podobieństwa obu umów wystarczają do tego, aby zakwalifikować umowę o udostępnienie skrytki sejfowej jako rodzaj umowy przechowania. Zdania na ten temat sa w doktrynie podzielone. $Z$ jednej strony wskazuje się na wyraźne podobieństwo obu umów ze względu na charakterystyczny dla nich obowiązek pieczy, z drugiej zaś podnosi się argumenty przeciwko takiej kwalifikacji. Wskazuje się przede wszystkim na realny charakter umowy przechowania, który jest sprzeczny z istotą umowy sejfowej. Ta polega bowiem na tym, że bank nie dostaje „do ręki” przedmiotów, a nawet nie wie, czy zostały one w skrytce złożone, czy pozostaje ona pusta. Ta ostatnia sytuacja nie wpływa na trwałość stosunku obligacyjnego.

${ }^{16}$ Zob. P. Bertran de Balanda, op. cit., s. 16.

17 Zob. Cour de cassation, Chambre commerciale, 11 Octobre 2005, nr 03-10975.

18 Zob. szerzej, S. Piedelièvre, op. cit., s. 2.

${ }^{19}$ Code civil - francuski kodeks cywilny - ustawa z 21 marca 1804 r. ze zm. 
Zwolennicy kwalifikacji umowy sejfowej jako rodzaju umowy przechowania powołują się na art. 1931 Code civil, który stanowi, że przechowawca nie musi wiedzieć, jakie przedmioty oddaje się na przechowanie, jeśli sa one umieszczone w zamkniętej kasetce albo kopercie; mogą one nie zawierać nawet żadnych przedmiotów. Co więcej, podnoszą oni, że składający może sam umieścić przedmioty w miejsce przechowania, tak jak klient banku sam umieszcza przedmioty w skrytce. Wskazują zatem na podobieństwo umowy przechowania do umowy sejfowej polegające na nieznajomości zawartości kasetki albo kufra, a także dyskrecji podczas ich opróżniania. Z kolei przeciwnicy takiego poglądu twierdza, że dla zawarcia umowy sejfowej decydującym elementem jest zaufanie, jakim klient darzy samą skrytkę, tzn. jej budowę i umieszczenie $\mathrm{w}$ banku, natomiast $\mathrm{w}$ umowie przechowania najważniejszy jest aspekt ludzki, czyli osoba przechowawcy i jego reputacja. Ponadto - zdaniem niektórych autorów - w sytuacji uzgodnienia przez strony umowy miejsca przechowania, z którego składajacy może dowolnie korzystać, nawet bez kontroli przechowawcy, nie można mówić o przechowaniu, tylko o umowie najmu

Udostępnienie skrytki bankowej porównuje się również z przechowaniem w hotelach (dépôt d’hôtellerie). Zgodnie z art. 1952 Code civil właściciele restauracji i hotelarze odpowiadaja jako przechowawcy za ubrania, bagaże i różne inne rzeczy wniesione przez swoich klientów, którzy wynajmuja u nich pokoje. Podobnie jak w przypadku skrytek bankowych także i tutaj właściciel hotelu nie wie, jakie przedmioty znajdują się w wynajętych pokojach, a mimo to ciąży na nich obowiązek pieczy wynikający z nałożonej na nich odpowiedzialności jako przechowawców. Według art. 1953 Code civil sa oni odpowiedzialni za kradzież albo uszkodzenie przedmiotu przechowania, jeśli zostały one wyrządzone przez pracowników hotelu albo osoby trzecie.

Jednak i w tej sytuacji podkreśla się różnice zachodzące między tymi dwoma kontraktami. Po pierwsze, przechowanie ma charakter akcesoryjny do umowy najmu, ale i konieczny ze względu na istotę działalności hoteli. Umowa sejfowa zaś takiego charakteru nie ma. Po drugie, w umowie najmu pokoju gość oddaje klucz do recepcji, a więc nie ma go cały czas przy sobie, hotel zaś dysponuje kluczami zapasowymi. W konsekwencji właściciel hotelu i jego pracownicy posiadaja prawie nieograniczony dostęp do wynajętego pomieszczenia. Dlatego też nie można mówić o dyskrecji czy bezpieczeństwie przedmiotów pozostawionych w pokojach. W istocie klient, zostawiając w nim swoje rzeczy, obdarza zaufaniem pracowników hotelu, a nie - jak to się dzieje w umowie sejfowej - konstrukcję samej skrytki.

Te wszystkie wątpliwości co do uznania umowy sejfowej za rodzaj umowy przechowania sprawiły, że zaczęto poszukiwać innych możliwości jej kwalifikacji. Część badaczy uznaje tę umowę za rodzaj umowy najmu. Ich zdaniem w sytuacji, gdy posiadacz skrytki może swobodnie umieszczać oraz wyjmować z niej przedmioty i nie można kwalifikować tych działań jako „wręczenie" charakterystyczne dla umowy przechowania, taki kontrakt powinien być zakwalifikowany jako najem ${ }^{20}$. Powołują się przy tym na regulacje kodekso-

${ }^{20}$ Tak M. Leven, op. cit., s. 248. 
we dotyczące tej umowy, które według nich nie stoją w sprzeczności z istota umowy o udostępnienie skrytki bankowej. Zgodnie bowiem z art. 1709 Code civil najem rzeczy jest umowa, przez która jedna ze stron umożliwia drugiej używanie rzeczy w określonym czasie za zapłatą wynagrodzenia. Jest to umowa konsensualna, do której zawarcia wystarczy samo oświadczenie woli stron.

Do obowiązków wynajmującego należy m.in. dostarczenie rzeczy w stanie pozwalającym na jej prawidłowe używanie oraz jej utrzymanie i konserwacja. Podobnie jak w przypadku umowy sejfowej, najem zakłada istnienie pewnej swobody działania najemcy, gdyż wynajmujący nie sprawuje kontroli nad korzystaniem z pokoju przez najemcę. Nie sprawdza on „wejść” ani „wyjść”, ani tego, co najemca zostawił w wynajmowanym pokoju. Nie powinien również wchodzić do pomieszczenia pod nieobecność najemcy. Wynajmujacy nie ma obowiązu pieczy nad przedmiotami umieszczonymi w wynajmowanym pomieszczeniu

Brak omawianego obowiązku w umowie sejfowej nie stanowi jednak, według części doktryny, przeszkody do kwalifikacji tej umowy jako rodzaju umowy najmu. Wyrazem tego stanowiska jest orzeczenie sądu z Tuluzy z 15 marca 1894 r. ${ }^{21}$, który orzekł, że w przypadku kradzieży wynajmujący jest zobowiązany do zapłaty odszkodowania, ponieważ w nocy najemca nie ma możliwości stałego nadzoru nad wynajętym pomieszczeniem. Zauważył on także, że wynajmujacy może zostać zwolniony od odpowiedzialności, jeśli wykaże, że dozorca dochował należytej staranności. Zatem sąd jednoznacznie opowiedział się za możliwością odpowiedzialności wynajmującego za szkodę, jaka powstała w czasie, gdy sam najemca nie mógł sprawować pieczy nad swoimi rzeczami. Może się on jednak od niej uwolnić, jeśli wykaże, że on albo dozorca dochował należytej staranności ${ }^{22}$. Orzeczenie to potwierdza, że najem nie wyklucza obowiązku pieczy, który może ciążyć na wynajmującym.

Warto zauważyć, że także w powszechnej świadomości wśród praktyków umowę sejfową uważa się za umowę najmu. Wyrazem tego jest nazywanie jej $\mathrm{w}$ regulaminach oraz w opracowaniach naukowych umową o najem skrytki bankowej. Według M. Schatza: „umowa o udostępnienie skrytki bankowej jest umową najmu rzeczy, przez którą wynajmujacy zobowiązuje się, za wynagrodzeniem, na określony czas udostępnić najemcy do używania skrytkę sejfowa, gwarantując bezpieczeństwo złożonych w niej przedmiotów”"23. W ostatnich latach wskazuje się jednak na niedoskonałości takiej kwalifikacji. Podnosi się przede wszystkim trzy argumenty.

Po pierwsze, że klient nie ma swobodnego dostępu do skrytki, tak jak najemca do wynajętej rzeczy. Po drugie, wyłącznie sam bank może kontrolować pomieszczenie, w którym znajdują się skrytki, a najemca nie ma wpływu na zabezpieczenia się w nim znajdujacee. Po trzecie, obowiązek pieczy spoczywający na banku jest silniejszy i bardziej intensywny niż u wynajmującego ${ }^{24}$. $\mathrm{W}$ umowie najmu ma on natomiast tylko akcesoryjny charakter i mimo że nie

\footnotetext{
21 Zob. szerzej ibidem, s. 250.

22 Ibidem, s. 248.

23 Ibidem.

${ }^{24}$ Zob. szerzej Ch. Gavalda, J. Stoufflet, op. cit., s. 586.
} 
stoi w sprzeczności z pozostałymi obowiązkami wynajmującego, to nie oddaje on istoty umowy sejfowej, w której obowiązek ten ma charakter podstawowy. Takie stanowisko znalazło także potwierdzenie w orzeczeniu Cour de cassation z 2005 r., według którego art. 1772 Code civil, a więc regulacje dotyczące umowy najmu, nie maja zastosowania do umowy sejfowej ${ }^{25}$.

Przyjmuje się zatem, że umowa sejfowa jest kontraktem o wiele bardziej złożonym niż umowa najmu. Ma ona hybrydowy charakter, gdyż łączy w sobie przechowanie i najem ${ }^{26}$. Jest kontraktem sui generis, należacym do grupy kontraktów opartych na obowiązku pieczy podobnie jak w umowach dotyczących pieczy nad miejscami parkingowymi, czy też magazynami. Uważa się, że taka kwalifikacja lepiej oddaje charakter umowy sejfowej, ponieważ podkreśla szczególny obowiązek banku, jakim jest piecza nad skrytką i obowiązek podejmowania wszelkich środków, w celu zapewnienia jej bezpieczeństwa i przedmiotów w niej złożonych ${ }^{27}$.

\section{ODPOWIEDZIALNOŚĆ UMOWNA BANKU}

Brak regulacji ustawowej i wątpliwości co do kwalifikacji umowy sejfowej sprawiaja, że strony same muszą zadbać o zabezpieczenie swoich interesów. Szczególnie bank będzie zainteresowany określeniem zakresu swojej odpowiedzialności. Zdaje on sobie bowiem sprawę, że skrytki nie gwarantuja całkowitego bezpieczeństwa złożonym w nim przedmiotom i zawsze istnieje, choćby minimalne, ryzyko pożaru lub powodzi, włamania czy też niedopatrzenia pracowników banku ${ }^{28}$. Pojawia się zatem pytanie, w jakiej wysokości bank powinien płacić odszkodowanie. Czy powinno się ono równać wartości złożonych rzeczy, czy jednak zostać ograniczone? Jeśliby przyjąc nieograniczona odpowiedzialność banku, mogłoby to prowadzić do wyłudzeń odszkodowań przez klientów, którzy mogliby twierdzić, że złożyli do skrytki bardzo drogie przedmioty.

Przyjmuje się, że bank powinien mieć możliwość ograniczenia swojej odpowiedzialności, skoro klient banku nie płaci wynagrodzenia za korzystanie ze skrytki proporcjonalnie do wartości przedmiotów w niej złożonych, a poza tym skrytka może pozostawać pusta i udowodnienie jej zawartości jest prawie niemożliwe. Wyrazem tego poglądu jest dopuszczalność wprowadzania do umowy sejfowej klauzul dwojakiego rodzaju.

Po pierwsze, klauzul, które mają na celu ograniczenie odpowiedzialności banku w przypadku wystapienia określonych w nich zdarzeń, np. powodzi czy też pożaru. Należy jednak pamiętać, że obowiąek banku do pieczy nad skrytką jest zobowiązaniem rezultatu i okolicznościami zwalniającymi bank

25 Zob. S. Piedelièvre, E. Putman, op. cit., s. 747; Cour de casssation, Chambre commerciale, 11 octobre 2005, nr 03-17.474.

26 Tak R. Routier, op. cit., s. 468.

27 Tak. S. Piedelièvre, op. cit., s. 524.

${ }_{28}$ Zob. szerzej R. Routier, op. cit., s. 468. 
od odpowiedzialności mogą być tylko siła wyższa i działanie samego uprawnionego. Klauzule zawierające inne okoliczności będą musiały zostać uznane za nieważne i bezskuteczne.

Po drugie, klauzul polegajacych na ustaleniu maksymalnej wartości przedmiotów, które mogą być złożone do skrytki. Ta maksymalna wartość byłaby zarazem kwota, do której wysokości bank ponosiłby odpowiedzialność w przypadku naruszenia swoich obowiązków umownych. Jeśli klient złożyłby do skrytki przedmioty, których wartość przekroczy kwotę ustaloną w umowie, to na nim ciążyłaby odpowiedzialność za naruszenie zobowiązania. Zarówno w praktyce, jak i doktrynie dopuszcza się możliwość wprowadzania do umowy takich klauzul ${ }^{29}$. Nie moga one jednak zmierzać to ograniczenia odpowiedzialności banku w sytuacji, gdy nie dopełnił on podstawowego ciążącego na nim obowiązku, czyli obowiązku pieczy nad skrytkę.

Z takim stanem faktycznym musiał zmierzyć się Cour de cassation w wyroku z 15 listopada $1988 \mathrm{r} \cdot{ }^{30}$ Dotyczył on sytuacji, gdy bank zawarł umowę skrytki sejfowej, wprowadzając do niej ograniczenie wartości złożonych w niej przedmiotów do 500000 franków. Klient jednak świadomie przekroczył ten limit, co nie uszło uwadze banku, i dlatego bank zaproponował mu równocześnie wykupienie dodatkowej polisy ubezpieczeniowej. Tymczasem skrytka została okradziona przez pracownika klienta, który podał się za upoważnionego do korzystania ze skrytki. Pracownik banku nie sprawdził jego umocowania, choć jak później zeznał: „osoba ta była upoważniona do otwierania skrytki, ale nigdy nie wchodziła do sali skrytek bez towarzystwa jednego lub kilku pełnomocników firmy"31.

$\mathrm{Na}$ tym tle zostały sformułowane trzy pytania: Czy przekroczenie maksymalnej wartości przedmiotów złożonych do skrytki przez klienta zwalnia bank z zobowiązania pieczy nad skrytka, a tym samym prowadzi do rozwiąznia umowy? Czy wobec zaniedbania ze strony banku, może on wciąż powoływać się na klauzulę ograniczającą wartość przedmiotów złożonych do skrytki, a tym samym maksymalną wartość odszkodowania? Czy klauzula określająca wartość przedmiotów, które mogą być złożone do skrytki, a tym samym ograniczająca jej zawartość, nie jest w istocie klauzulą ograniczającą odpowiedzialność banku? $?^{32}$

Sąd orzekł, że przekroczenie ustalonej w umowie wartości przedmiotów mogących być złożonych w skrytce nie powoduje automatycznego ustania obowiązu dozoru i rozwiązania umowy. W takiej sytuacji maksymalne odszkodowanie, którego będzie mógł domagać się klient w razie naruszenia obowiązków umownych przez bank, nie będzie mogło przewyższać ustalonego przez strony limitu wartości przedmiotów. Jeśli zaś bank dopuszcza się zaniedbania swojego obowiązku sprawdzania upoważnień osób chcących uzyskać dostęp do skrytki i popełnia tym samym „rażące niedbalstwo” (tzw. faute lourde), nie

${ }^{29}$ Ibidem, s. 469.

${ }^{30}$ Zob. Ch.-H. Gallet, Contrat de coffre-fort, „Revue de jurisprudence commerciale” 1989, nr 1, s. 107-111.

${ }^{31}$ Zob. idem, Contrat de coffre-fort, „Revue de jurisprudence commerciale” 1987, nr 1, s. 146.

${ }^{32}$ Idem, Contrat de coffre-fort, „Revue de jurisprudence commerciale”1989, nr 1, s. 107-111. 
może się powoływać na ograniczenie swojej odpowiedzialności zamieszczone w klauzuli określającej jej pułap. W takiej sytuacji bank jest odpowiedzialny za szkodę niezależnie od tego, czy klient przekroczył dopuszczalną wartość przedmiotów mogących znaleźć się w skrytce, i to w pełnej wysokości. Klauzula określająca zawartość skrytki nie jest wówczas traktowana jako klauzula ograniczająca odpowiedzialność banku.

W rozważaniach dotyczacych klauzul umownych należy również wspomnieć o postanowieniach, których zamieszczenie w umowie sejfowej jest niedopuszczalne. Zgodnie z zaleceniami komisji do spraw klauzul abuzywnych z 21 listopada 1986 r. są nimi postanowienia, które mają na celu zwolnienie banku z wszelkiej odpowiedzialności w przypadku włamania się do skrytki, postanowienia ograniczające kwotę odszkodowania za szkodę poniesioną w razie włamania bez zaoferowania klientowi możliwości pełnego pokrycia tego ryzyka przez podwyższenie opłaty umownej oraz ograniczające odszkodowanie należne klientowi nawet wtedy, gdy szkoda jest wynikiem rażącego niedbalstwa popełnionego przez wynajmującego ${ }^{33}$.

Dopuszcza się natomiast umieszczenie w umowie sejfowej klauzul wyłaczających odpowiedzialność banku w sytuacji, gdy szkoda wynikła z winy samego uprawnionego, a także gdy została ona spowodowana przez siłę wyższa (fr. force majeure). Pojęcie to zostało doprecyzowane przez doktrynę i orzecznictwo sądowe. To, jakie okoliczności można i należy uznać za działanie siły wyższej, ma szczególne znaczenie dla banku i dlatego w jego interesie będzie leżało ustalenie jak najszerszego katalogu zdarzeń, które mogą być traktowane jako działanie siły wyższej. Taka interpretacja mogłaby jednak doprowadzić do nieuzasadnionego uprzywilejowania banku, który ze względu na możliwość zwolnienia się z odpowiedzialności z błahych czasem powodów mógłby nie dokładać odpowiednich starań przy zapewnieniu skrytce należytej ochrony. $\mathrm{Z}$ tych powodów doktryna i orzecznictwo francuskie bardzo wąsko interpretuja pojęcie „,siła wyższa”.

Taki charakter ma wyłacznie zdarzenie, które jest niemożliwe do przewidzenia, niemożliwe do zapobieżenia oraz mające charakter zewnętrzny, tzn. jego źródło leży poza skrytką, z której to ochroną wiąże się odpowiedzialność odszkodowawcza ${ }^{34}$. O „przewidywalności” zdarzenia stanowi art. 1150 Code civil, zgodnie z którym, dłużnik jest odpowiedzialny wyłącznie za szkody, które zostały albo mogły zostać przewidziane przez strony w czasie trwania kontraktu. Przepis ten nie wskazuje jednak, o jakie dające się przewidzieć zdarzenia chodzi. Pomocne w ich ustaleniu są orzeczenia sądów francuskich, które wymieniaja, jakie okoliczności należy traktować jako działanie siły wyższej. Nie należą do nich np. napad, włamanie, czy też pożar, ponieważ odmawia się im przymiotu nieprzewidywalności ${ }^{35}$. Cechę tę posiadają natomiast takie zdarzenia, jak np. trzęsienie ziemi i wojna, i to ich wystapienie zwalnia bank z odpowiedzialności ${ }^{36}$.

\footnotetext{
${ }^{33}$ S. Piedelièvre, E. Putman, op. cit., s. 751.

${ }^{34}$ M. Cabrillac, B. Teyssié, op. cit., s. 546.

35 Zob. Cour de cassation, Chambre commerciale, 11 Octobre 2005, nr 03-10975.

${ }^{36}$ F. Dekeuwer-Défossez, S. Moreil, op. cit., s. 187.
} 
Ciężar dowodu spoczywa, zgodnie z zasadami ogólnymi, na kliencie, który powinien udowodnić, że - po pierwsze - umieścił określone przedmioty w skrytce, a po drugie, że skrytka została naruszona w wyniku np. włamania $^{37}$. W praktyce bardzo trudno będzie udowodnić fakt złożenia przedmiotów złożonych do skrytki. Łatwiejsze do udowodnienia staje się naruszenie skrytki, ponieważ włamanie, powódź czy pożar zostawiają widoczne ślady.

\section{PEENOMOCNICTWO DO KORZYSTANIA ZE SKRYTKI BANKOWEJ}

Z zagadnieniem odpowiedzialności banku wiąże się także kwestia pełnomocnictwa. Klient banku może bowiem ustanowić pełnomocnika, który będzie upoważniony do korzystania ze skrytki. Pojawia się zatem pytanie, czy takie umocowanie obejmuje także możliwość składania do skrytki przedmiotów należących do pełnomocnika. Jeśli odpowie się na nie twierdząco, to pojawia się kolejne pytanie, a mianowicie: Czy bank jest odpowiedzialny także za utratę tych przedmiotów, skoro stroną umowy jest wyłącznie klient? Kwestię tę rozstrzyga orzeczenie sądu z 29 marca $1989 \mathrm{r}^{38} \mathrm{~W}$ analizowanym stanie faktycznym klient po zawarciu z bankiem umowy o udostępnienie skrytki sejfowej udzielił pełnomocnictwa innej osobie, która złożyła do skrytki przedmioty będące jej własnością. W wyniku kradzieży, która miała miejsce w tym banku, skrytka ta została opróżniona z zawartości i klient banku wraz ze swoim pełnomocnikiem wystapili o odszkodowanie. Sąd orzekł, że bank, na którym ciąży zobowiązanie rezultatu, jest odpowiedzialny względem osoby, która wynajęła skrytkę, za kradzież wszystkich przedmiotów w niej się znajdujących bez względu na to, czy należą one do posiadacza skrytki, czy też do jego pełnomocnika.

W doktrynie szuka się jednak uzasadnienia tego rozstrzygnięcia, gdyż z samego zobowiązania rezultatu, które obciąża bank, nie wynika domniemanie, że jest on zobowiązany erga omnes. Wręcz przeciwnie, w treści umowy określa się jednoznacznie nie tylko, kto jest jej strona, lecz także, jaki rezultat poprzez jej zawarcie ma zostać osiagnięty. Tym rezultatem jest zapewnienie ochrony skrytki i przedmiotów w niej złożonych przez posiadacza. Sąd zatem, rozszerzając zakres odpowiedzialności banku także na przedmioty złożone przez pełnomocnika, dokonał ingerencji w umowę zawartą między bankiem a posiadaczem skrytki. Stanowi ona przykład „wymuszenia umownego”, gdyż choć samo pełnomocnictwo w przedstawionym stanie faktycznym uprawniało pełnomocnika do dostępu do skrytki i wyjmowania jej zawartości na rzecz mocodawcy, to sąd dopuścił odpowiedzialność banku także wobec pełnomocnika. Jest to z pewnością rozwiązanie o dużym walorze praktycznym, ponieważ ze

37 S. Piedelièvre, op. cit., s. 4.

38 E. Putman, B. Solletty, Banque-Banquier, „Semaine juridique”, édition generale G 1990, nr 9, s. 21415 . 
względu na obowiązek tajemnicy bankowej bank nie ma możliwości sprawdzenia pochodzenia przedmiotów złożonych do skrytki.

Uzasadnień takiego rozstrzygnięcia jest kilka. Po pierwsze, w doktrynie pojawiły się głosy, aby przyjąć koncepcję substytucji. Polegałaby ona na tym, że pełnomocnik ,wchodziłby” w prawa i obowiązki posiadacza skrytki, będącego stroną umowy zawieranej z bankiem. Rozstrzygnięcie to nie rozwiąuje jednak problemu, ponieważ nie wynika ono z treści umowy, a trudno je domniemywać. Wydaje się także niedopuszczalne ze względu na sens umowy sejfowej, nawet gdyby bank przyznał klientowi możliwość substytucji. Domniemywa się bowiem, że przedmioty złożone w skrytce należą do klienta.

Po drugie, rozszerzenie przez sąd obowiązku pieczy na przedmioty należące do pełnomocnika mogłoby zostać oparte na koncepcji tzw. łańcucha umów. Została ona wyrażona w wyroku z 21 czerwca 1988 r., według którego „w grupie umów odpowiedzialność umowna dopuszcza powództwo o odszkodowanie dla tych osób, które miały związek z umową wyjściowa" ${ }^{39}$. Należałoby się zatem zastanowić, $\mathrm{z}$ istnieniem jakich umów mamy do czynienia w powyżej omawianej sytuacji. Czy z umowa najmu skrytki i depozytu dla pełnomocnika, wynikajaca z samego faktu udzielenia pełnomocnictwa?

Po trzecie, w doktrynie pojawiaja się także propozycje potraktowania umowy sejfowej i pełnomocnictwa udzielonego przez klienta banku osobie trzeciej jako umowy trójstronnej, w której pełnomocnik zostałby „włączony” do umowy o udostępnienie skrytki.

Niezależnie od przyjęcia którejś z referowanych powyżej koncepcji, sąd dopuścił odpowiedzialność banku względem pełnomocnika. Co więcej, sąd uznał legitymację czynną klienta banku do wytoczenia powództwa o odszkodowanie na rzecz pełnomocnika, mimo że w przedstawionym powyżej stanie faktycznym sam posiadacz skrytki nie domagał się odszkodowania dla siebie.

\section{PODSUMOWANIE}

Przeprowadzone rozważania upoważniają do sformułowania kilku wniosków, u których podstaw leży stwierdzenie, że analiza rozważanej tu umowy w prawie francuskim jest ważna dla rozwiązań proponowanych w prawie polskim ze względu na podobieństwo francuskiego i polskiego prawa kontraktów.

Po pierwsze, francuska doktryna i orzecznictwo podejmowały liczne problemy związane z umową sejfowa. Aktywność tę uzasadnia nie tylko wzrost znaczenia tej umowy, lecz także brak jej regulacji ustawowej, z pozostawieniem sprecyzowania treści umowy samym stronom, przy dominującej pozycji banku. Przedkłada on bowiem wzór umowy, który klient podpisuje, aby doprowadzić do jej zawarcia. Również w Polsce ciężar konkretyzacji treści tej umowy spoczywa na stronach, a punktem odniesienia jest regulamin opracowany

${ }^{39}$ Zob. szerzej ibidem, s. 21414-21416. 
przez bank. Można zatem zakładać, że także w naszym kraju ulegnie wzmocnieniu potrzeba rozstrzygania wielu kwestii dotyczacych umowy sejfowej.

Po drugie, zagadnieniem o największej doniosłości praktycznej jest określenie praw i obowiązków stron umowy, a przede wszystkim zakresu odpowiedzialności banku. Powinien być on tak ustalony, by zapewnić maksymalna ochronę osobom korzystającym ze skrytek bankowych. Z tego punktu widzenia należy również analizować umowę o udostępnienie skrytki bankowej w prawie polskim. Niektóre problemy zwiąane z określeniem zakresu odpowiedzialności banku stały się już przedmiotem orzeczeń Sądu Najwyższego ${ }^{40}$.

Po trzecie, podstawowym zagadnieniem teoretycznym, ale mającym implikacje praktyczne, jest określenie charakteru prawnego umowy sejfowej. W nauce francuskiej, jak pokazano, występuje cała mozaika poglądów. Również, jak wcześniej wspomniano, takie zróżnicowanie poglądów występuje w nauce polskiej. Wydaje się, że określenie charakteru rozważanej tu umowy powinno mieć na uwadze zapewnienie jak najszerszej ochrony klientów banku i bezpieczeństwa obrotu.

mgr Marta Budzinowska

Uniwersytet im. Adama Mickiewicza w Poznaniu

martab@amu.edu.pl

\title{
CONTRACT FOR A SAFE DEPOSIT BOX UNDER FRENCH LAW
}

\author{
Sum mary
}

Polish law contains no provision governing a contract for a safe deposit box. What is more, neither the doctrine, nor the judicial decisions seem to pay much attention to that type of contract. In France, however, problems that may arise out of such contracts (French: contrat de location de coffre-fort) have been for long recognised and addressed by courts and judges, resulting in a handful of judgments and decisions on the matter.

The deliberations in this paper focus of the main aspects of a contract for a safe deposit box under French law, such as entering into a contract for safe deposit, parties to a contract and their rights and obligations, the bank's liability for non-performance or negligent performance of its obligation, or a power of attorney authorising an agent to use a safe deposit box.

It is concluded that in France, as well as in Poland, both parties are responsible for drafting a contract which is, nevertheless, based on the regulations developed by the bank. For practical reasons, it is extremely vital to precisely determine the rights and obligations of both parties, and the extent of bank's liability, in particular. Thus a contract for a safe deposit box should ensure the best possible protection of the party using a safe deposit box, while the main theoretical issue, although also with practical application, is that of determination of the legal nature of a safe deposit contract.

40 Zob. np. wspomniany już wyrok Sacu Najwyższego z 26 lipca 2001 r., II CKN 1269/00, z aprobującymi glosami A. Janiaka (OSP 2002, nr 9, poz. 121) i D. Ambrożuk („Państwo i Prawo” 2013, z. 1). 
Copyright of Journal of Law, Economics and Sociology is the property of Faculty of Law and Administration of Adam Mickiewicz University in Poznan and its content may not be copied or emailed to multiple sites or posted to a listserv without the copyright holder's express written permission. However, users may print, download, or email articles for individual use.

Właścicielem praw autorskich do „Ruchu Prawniczego, Ekonomicznego i Socjologicznego” jest Wydział Prawa i Administracji Uniwersytetu im. Adama Mickiewicza w Poznaniu. Zawartość czasopisma nie może być kopiowana, przesyłana do innych stron internetowych bądź zamieszczana na blogach bez pisemnej zgody wydawcy. Niemniej artykuły można drukować, kopiować lub przesyłać w formie elektronicznej na własny użytek. 